
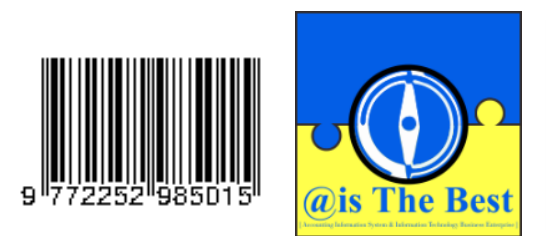

Volume 03, Nomor 02

Desember 2018

P-ISSN: 2252-9853

E-ISSN:

DOI:

\title{
Analisis Estimasi Waktu Penyelesaian Proyek Perangkat Lunak Menggunakan Metode PERT
}

\author{
Gentisya Tri Mardiani \\ Program Studi Teknik Informatika, Fakultas Teknik dan Ilmu Komputer \\ Universitas Komputer Indonesia \\ Jalan Dipatiukur No. 112-116 Bandung \\ Email: gentisya.tri.mardiani@email.unikom.ac.id
}

\begin{abstract}
Keywords:
Estimate; schedule; probability; poject software

Abstract

Planning the schedule on the construction project software in general is based on experience from a previous project, so that in determining the duration of work using only one of the estimate, or the duration for every job has been set directly by the Project Manager or Project Team in the company. This resulted in when the construction project, when there was the problem of lack of progress, Project Manager of not knowing the possibility of whether the project can continue to run as planned or not. In addition, the determination of one of the estimate for the duration of work not suitable with the characteristics of the software, because in the construction project software there is still uncertainty in the time the completion of projects. The weakness in the use of the value of the estimated duration of is when there are problems that can not be predicted with certainty the length of it, resulting in the duration of work has been set for later employment should be set back, causing projects to be too late. Based on the problem needed an analysis to determine the probability of the completion of projects using the method of program Evaluation and Review Technique (PERT), this method employs three estimates of the duration of the duration of optimistic, the duration of the most likely and the duration of the pessimistic. It is expected to know the time the completion of projects, Project Manager can do the planning of the scheduling of the project. The result of this study shows that the probabilities of the completion of projects can be counted when Project Manager already know the duration of the critical of the schedule the construction project.
\end{abstract}

\section{Kata Kunci:}

Estimasi; Jadwal; Probabilitas; Proyek Perangkat Lunak

\section{Abstrak}

Perencanaan jadwal pada pengerjaan proyek perangkat lunak pada umumnya dilakukan berdasarkan pengalaman dari proyek sebelumnya, sebingga dalam penentuan durasi pekerjaan hanya menggunakan satu nilai estimasi, atau durasi untuk setiap pekerjaan sudah ditentukan langsung oleh Project Manager atau Project Team dalam perusahaan. Hal tersebut berakibat pada saat pengerjaan proyek, ketika terjadi permasalaban keterlambatan pengerjaan, Project Manager belum mengetabui kemungkinan apakah proyek dapat tetap berjalan sesuai rencana atau tidak. Selain itu, penentuan satu nilai estimasi terbadap durasi pekerjaan belum cocok dengan karakteristik dari proyek, perangkat lunak, karena dalam pengerjaan proyek perangkat lunak masib terdapat ketidakpastian yang lebih pada waktu penyelesaian proyek. Kelemahan dalam penggunaan satu nilai estimasi durasi adalah ketika terdapat permasalahan teknis yang tidak dapat diprediksi dengan pasti durasinya, mengakibatkan durasi pekerjaan yang sudah ditentukan untuk pekerjaan selanjutnya harus ditentukan kembali, sehingga menyebabkan proyek. 
menjadi terlambat. Berdasarkan permasalahan tersebut dibutubkan suatu analisis untuk mengetahui probabilitas penyelesaian proyek menggunakan metode Program Evaluation and Review Technique (PERT), metode ini menggunakan tiga nilai estimasi durasi yaitu durasi optimistis, durasi most likely dan durasi pesimistis. Sebingga diharapkan dengan mengetabui estimasi waktu penyelesaian proyek, Project Manager dapat melakukan perencanaan penjadwalan proyek. Hasil dari penelitian ini menunjuke an bahwa probabilitas penyelesaian proyek dapat dibitung ketika Project Manager sudah mengetahui durasi kritis dari jadwal pengerjaan proyek.

\section{PENDAHULUAN}

\section{Latar Belakang}

Proyek perangkat lunak pada saat ini sudah menjadi kebutuhan di kalangan industri maupun perusahaan yang bergerak di bidang Teknologi Informasi. Berdasarkan pada kebutuhan akan pengerjaan proyek khususnya pembangunan perangkat lunak, maka berkembang juga perusahaan yang menyediakan jasa untuk pengerjaan poroyek perangkat lunak. Dalam pengerjaan suatu proyek, Project Manager perlu melakukan tahapan perencanaan agar proyek dapat berjalan sesuai dengan kontrak waktu yang sudah ditetapkan atau disepakati dalam kontrak proyek. Tahapan yang dilakukan pada tahap perencanaan meliputi perencanaan jadwal, biaya, risiko, maupun sumber daya manusia.

Pada tahap perencanaan jadwal proyek, Project Manager akan menentukan urutan pekerjaan yang akan dilakukan selama proyek berlangsung, urutan pekerjaan dan durasi pengerjaan proyek akan disesuaikan dengan jenis proyek perangkat lunak yang akan dikerjakan. Selain itu, urutan pekerjaan dan durasi dalam pengerjaan proyek perangkat lunak juga dapat disesuaikan dengan kebutuhan klien, atau sesuai dengan kompleksitas suatu proyek. Berdasarkan hal tersebut, karakterisitik suatu proyek perangkat lunak memiliki tingkat ketidakpastian yang tinggi untuk waktu penyelesaian proyek. Namun saat ini, Project Manager dalam melakukan perencanaan jadwal proyek dilakukan berdasarkan pengalaman dari proyek sebelumnya sehingga dalam penentuan durasi pekerjaan hanya menggunakan satu nilai estimasi, atau durasi untuk setiap pekerjaan sudah ditentukan. Hal tersebut berakibat pada saat pengerjaan proyek, ketika terjadi permasalahan keterlambatan pengerjaan, Project Manager belum mengetahui kemungkinan apakah proyek dapat tetap berjalan sesuai rencana atau tidak, sehingga mengakibatkan penyelesaian proyek menjadi terlambat.

Berdsasarkan penelitian yang sudah dilakukan sebelumnya, menurut (Mas'ud dan Wijayanti, 2017) menjelaskan bahwa penggunaan metode Program Evaluation and Review Technic (PERT) digunakan untuk mengetahui jaringan kerja dari suatu pekerjaan proyek, dan dengan menghitung menggunakan tiga nilai estimasi durasi waktu, suatu pengerjaan proyek dapat diketahui tingkat probabilitas proyek tersebut dapat selesai tepat pada waktu yang telah ditetapkan [3].

Berdasarkan permasalahan yang sudah dijelaskan, bahwa Project Manager dalam melakukan perencanaan jadwal pengerjaan proyek perangkat lunak yang memiliki karakteristik memiliki tingkat ketidakpastian yang tinggi dalam waktu penyelesaianya, maka Poject Manager perlu mengetahui tingkat probabilitas proyek yang akan dikerjakan, agar proyek tersebut diharapkan dapat berjalan sesuai pada waktunya, dan Project Manager dapat mengambil keputusan ketika terjadi permasalahan pada saat proyek berlangsung.

\section{Perumusan Masalah}

Berdasarkan uraian sebelumnya, maka dapat dirumuskan masalah yang terjadi adalah bagaimana melakukan analisis untuk mengetahui estimasi waktu penyelesaian suatu proyek perangkat lunak. 


\section{Tujuan Penelitian}

Adapun tujuan dari penelitian ini yaitu dapat membantu Project Manager dalam mengetahui probabilitas tingkat suatu keberhasilan penyelesaian proyek perangkat lunak.

\section{Manfaat Penelitian}

Manfaat penelitian ini adalah Project Manager dapat mengetahui probabilitas tingkat keberhasilan suatu proyek perangkat lunak yang akan dikerjakan, sehingga dapat merencanakan bagaimana cara mengatasi masalah yang dapat terjadi pada saat proyek berlangsung.

\section{Batasan Masalah}

Adapun batasan masalah dalam penelitian ini adalah:

1. Data yang digunakan dalam penelitian ini meliputi: data uraian pekerjaan, data jadwal, dan data struktur organisasi proyek.

2. Metode yang digunakan untuk menggambarkan urutan pekerjaan menggunakan jaringan kerja/ diagram network

3. Metode yang digunakan dalam mengetahui estimasi waktu penyelesaian proyek menggunakan Program Evaluation and Review Technic (PERT)

\section{METODE PENELITIAN}

Metode penelitian yang digunakan menggunakan metode deskriptif. Tahapan yang dilakukan dalam penelitian ini dapat dilihat pada gambar 1 berikut.

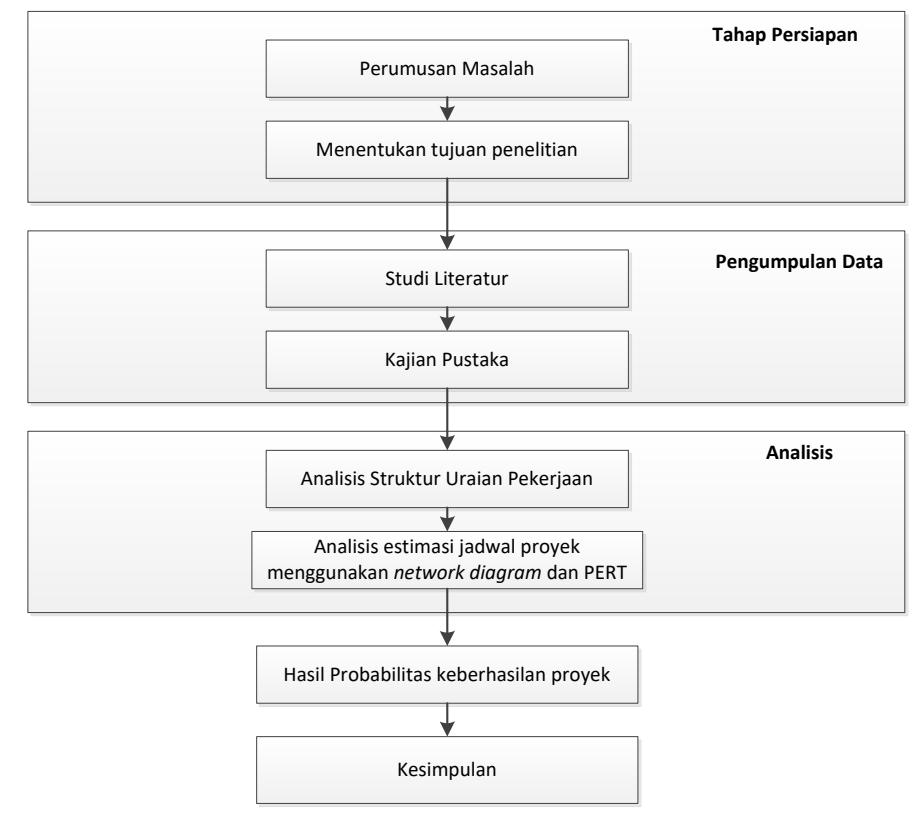

Gambar 1 Metode Penelitian

\section{HASIL DAN PEMBAHASAN}

Studi kasus yang dijadikan bahan pada penelitian ini adalah proyek Pengadaan dan Renewal Lisensi Email dengan anggaran biaya sebesar Rp560.175.000 (Lima Ratus Enam Puluh Juta Seratus Tujuh Puluh Lima Ribu Rupiah) didalamnya sudah termasuk PPN dan pajak lainnya yang berlaku, serta lama pelaksanaan 90 hari, karena hari libur sabtu dan minggu tidak dihitung maka menjadi 66 hari. Dimulai dari tanggal 22 April 2016 sampai dengan 22 Juli 2016. Studi kasus ini berdasarkan penelitian sebelumnya (Munandar, 2017) [2]

Gambar 2 berikut adalah struktur organisasi proyek yang ada pada proyek perangkat lunak Pengadaan dan Renewal Lisensi Email Badan Informasi Geospasial. 


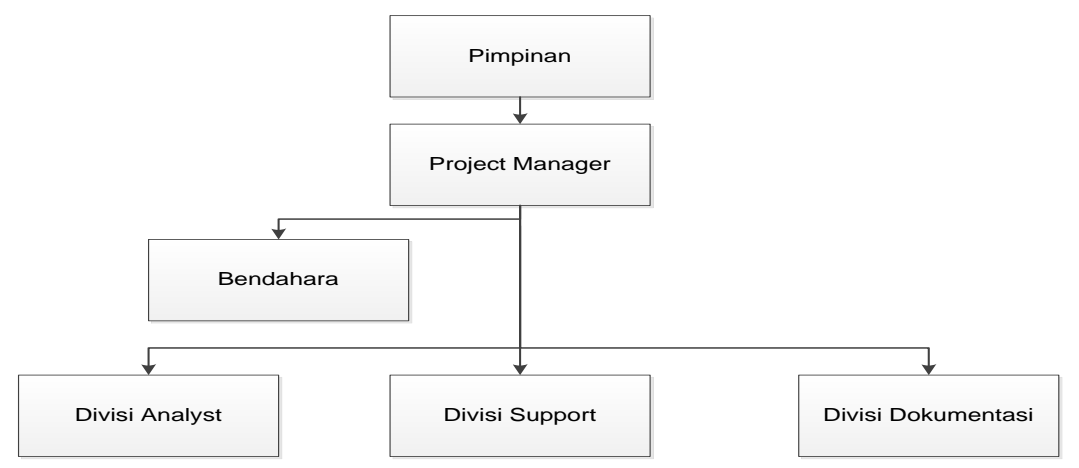

Gambar 2 Struktur Organisasi Proyek

Berdasarkan struktur organisasi proyek yang sudah ditentukan, kemudian Project Manager akan membuat uraian struktur pekerjaan dari proyek. Uraian struktur pekerjaan dapat dilihat pada tabel 1 berikut.

Tabel 1 Struktur Pekerjaan

\begin{tabular}{|c|l|}
\hline No & \multicolumn{1}{|c|}{ Struktur Pekerjaan } \\
\hline A & Pengadaan Lisensi \\
\hline B & Instalasi Server \\
\hline C & Instalasi \& Konfigurasi Serta Improvement Zimbra Mail Server \\
\hline D & Konfigurasi Meningkatkan Reputasi Email \\
\hline E & Migrasi Data \\
\hline F & Ujicoba Pengiriman Dan Penerimaan \\
\hline G & Pendampingan (Support) \& Dokumentasi Sistem \\
\hline H & Proses Switching Sistem \\
\hline I & Transfer Knowledge \\
\hline
\end{tabular}

Berdasarkan struktur pekerjaan yang sudah dibuat, kemudian ditentukan nilai optimis dan pesimis dari setiap pekerjaan. Nilai optimis dan pesimistis ditentukan berdasarkan hasil wawancara langsung dengan Project Manager. Nilai optimis merupakan nilai tercepat dalam mengerjakan suatu pekerjaan, sedangkan nilai pesimistis merupakan waktu terlama dalam menyelesaikan pekerjaan. Struktur pekerjaan dan nilai durasi optimis, pesimis, dan most likely pada pelaksanaan proyek Pengadaan dan Renewal Lisensi Email dapat dilihat pada Tabel 2.

Tabel 2 Durasi Pekerjaan

\begin{tabular}{|c|l|c|c|c|}
\hline \multirow{2}{*}{ No } & \multicolumn{1}{|c|}{ Struktur Pekerjaan } & \multicolumn{3}{|c|}{ Durasi } \\
\cline { 3 - 5 } & & $\begin{array}{c}\text { Optimis } \\
\text { (a) (hari) }\end{array}$ & $\begin{array}{c}\text { Most Likely } \\
\text { (m) (hari) }\end{array}$ & $\begin{array}{c}\text { Pesimistis } \\
\text { (b) (hari) }\end{array}$ \\
\hline A & Pengadaan Lisensi & 14 & 17 & 20 \\
\hline B & Instalasi Server & 4 & 5 & 6 \\
\hline C & $\begin{array}{l}\text { Instalasi \& Konfigurasi Serta } \\
\text { Improvement Zimbra Mail Server }\end{array}$ & 8 & 10 & 13 \\
\hline D & $\begin{array}{l}\text { Konfigurasi Meningkatkan } \\
\text { Reputasi Email }\end{array}$ & 1 & 3 & 5 \\
\hline E & Migrasi Data & 5 & 7 & 11 \\
\hline F & $\begin{array}{l}\text { Ujicoba Pengiriman Dan } \\
\text { Penerimaan }\end{array}$ & 1 & 1 & 2 \\
\hline G & $\begin{array}{l}\text { Pendampingan (Support) \& } \\
\text { Dokumentasi Sistem }\end{array}$ & 5 & 6 & 7 \\
\hline H & Proses Switching Sistem & 1 & 2 & 3 \\
\hline I & Transfer Knowledge & 4 & 5 & 6 \\
\hline
\end{tabular}


Berdasarkan data pada tabel 2 sudah didapatkan nilai optimis, most likely dan pesimistis dari setiap kegiatan. Berikut adalah perhitungan expected time, standard deviasi dan variansi dari kegiatan rincian durasi pekerjaan berdasarkan metode PERT [4]. Berikut penjelasan untuk menghitung nilai expected time, sebagai contoh untuk pekerjaan A:

Diketahui: a: 14, m: 17, b: 20

\section{Expected:}

$$
\begin{aligned}
\text { Expected Time } & =\frac{(a+4 m+b)}{6} \\
= & \frac{(14+4.17+20)}{6} \\
= & \frac{(14+68+20)}{6} \\
= & \frac{102}{6} \\
& =17 \text { Hari }
\end{aligned}
$$

\section{Standard Deviasi:}

$$
\begin{gathered}
\text { Standard Deviasi }=\frac{(b-a)}{6} \\
=\frac{(20-14)}{6}=1
\end{gathered}
$$

\section{Variansi:}

\begin{tabular}{|c|c|c|c|c|c|c|}
\hline Aktivitas & a & m & $\mathbf{b}$ & $\begin{array}{c}\text { Expected } \\
\text { (hari) }\end{array}$ & $\begin{array}{c}\text { Standard } \\
\text { Deviasi }\end{array}$ & Variansi \\
\hline A & 14 & 17 & 20 & 17 & 1 & 1 \\
\hline $\mathrm{B}$ & 4 & 5 & 6 & 5 & 0,5 & 0,25 \\
\hline $\mathrm{C}$ & 8 & 10 & 13 & 10 & 0,84 & 0,71 \\
\hline $\mathrm{D}$ & 1 & 3 & 5 & 3 & 0,67 & 0,45 \\
\hline $\mathrm{E}$ & 5 & 7 & 11 & 7 & 1 & 1 \\
\hline$F$ & 1 & 1 & 2 & 2 & 0,17 & 0,03 \\
\hline$G$ & 5 & 6 & 7 & 5 & 0,34 & 0,12 \\
\hline $\mathrm{H}$ & 1 & 2 & 3 & 2 & 0,34 & 0,12 \\
\hline $\mathrm{I}$ & 4 & 5 & 6 & 5 & 0,34 & 0,12 \\
\hline \multicolumn{4}{|c|}{ TOTAL } & 56 Hari & 5,2 & 3,8 \\
\hline
\end{tabular}

$$
\begin{aligned}
\text { Variansi } & =\left\{\frac{(b-a)}{6}\right\}^{2} \\
= & 1^{2}=1
\end{aligned}
$$

Berdasarkan perhitungan yang sudah dilakukan. Maka untuk pekerjaan A dihasilkan expected time yaitu 17 Hari, nilai standard deviasi $=1$ dan nilai variansi $=1$. Tabel berikut merupakan hasil rekapitulasi perhitungan nilai expected time, standar deviasi, dan nilai variansi untuk setiap pekerjaan.

Tabel 3 Rekapitulasi Hasil Perhitungan

Berdasarkan nilai expected time (te) yang sudah diketahui, kemudian durasi tersebut digunkanan untuk menggambarkan urutan pekerjaan menggunakan diagram jaringan kerja 
Menggunakan Metode PERT

(network diagram). Tabel 4 berikut adalah struktur pekerjaan yang akan digunakan untuk menggambarkan netowrk diagram.

Tabel 4 Struktur Pekerjaan dengan kegiatan pendahulu

\begin{tabular}{|c|l|c|c|c|}
\hline Node & \multicolumn{1}{|c|}{ Struktur Pekerjaan } & $\begin{array}{c}\text { Kode } \\
\text { Aktivitas }\end{array}$ & $\begin{array}{c}\text { Kegiatan } \\
\text { Pendahulu }\end{array}$ & Te \\
\hline 0 & Mulai & Mulai & - & - \\
\hline 1 & Pengadaan Lisensi & A & Mulai & 17 \\
\hline 2 & Instalasi Server & B & A & 5 \\
\hline 3 & $\begin{array}{l}\text { Instalasi \& konfigurasi serta } \\
\text { improvement Zimbra Mail } \\
\text { Server }\end{array}$ & C & B & 10 \\
\hline 4 & $\begin{array}{l}\text { Konfigurasi Meningkatkan } \\
\text { reputasi email }\end{array}$ & D & C & 3 \\
\hline 5 & Migrasi Data & E & D & 7 \\
\hline 6 & $\begin{array}{l}\text { Ujicoba Pengiriman dan } \\
\text { Penerimaan }\end{array}$ & F & D & 2 \\
\hline 7 & $\begin{array}{l}\text { Pendampingan (Support) \& } \\
\text { Dokumentasi Sistem }\end{array}$ & G & E, F & 5 \\
\hline 8 & Proses Switching Sistem & H & E, F & 2 \\
\hline 9 & Proses Transfer Knowledge & I & G, H & 5 \\
\hline
\end{tabular}

Berdasarkan tabel tersebut, kemudian digambarkan network diagramnya, lalu dihitung nilai ES dan EF dengan perhitungan maju, dan nilai LF,LS dengan perhitungan mundur, kemudian diketahui nilai Total Float (TF) atau waktu jeda untuk setiap kegiatan. Hal ini digunakan untuk mengetahui nilai durasi kritis, yaitu pekerjaan yang tidak memiliki TF maka pekerjaan tersebut termasuk ke dalam jalur kritis yang pengerjaannya tidak dapat ditunda. Tabel 5 berikut merupakan hasil perhitungan TF keseluruhan.

Tabel 5 Rekapitulasi perhitungan Total Float

\begin{tabular}{|c|c|c|c|c|c|c|c|c|}
\hline \multirow{2}{*}{$\begin{array}{c}\text { Kode } \\
\text { Kegiatan }\end{array}$} & \multicolumn{2}{|c|}{ Kegiatan } & \multirow{2}{*}{$\begin{array}{c}\text { Waktu } \\
\text { (Te) } \\
\text { Dalam } \\
\text { hari }\end{array}$} & \multicolumn{2}{|c|}{ Paling Awal } & \multicolumn{2}{|c|}{ Paling Akhir } & \multirow{2}{*}{$\begin{array}{l}\text { Total } \\
\text { Float }\end{array}$} \\
\hline & i-node & j-node & & $\begin{array}{c}\text { Mulai } \\
\text { (ES) }\end{array}$ & $\begin{array}{l}\text { Selesai } \\
\text { (EF) }\end{array}$ & $\begin{array}{c}\text { Selesai } \\
\text { (LF) }\end{array}$ & $\begin{array}{c}\text { Awal } \\
\text { (LS) }\end{array}$ & \\
\hline A & 0 & 1 & 17 & 0 & 17 & 52 & 47 & 0 \\
\hline B & 1 & 2 & 5 & 17 & 22 & 47 & 42 & 0 \\
\hline $\mathrm{C}$ & 2 & 3 & 10 & 22 & 32 & 47 & 45 & 0 \\
\hline $\mathrm{D}$ & 3 & 4 & 3 & 32 & 35 & 42 & 35 & 0 \\
\hline $\mathrm{E}$ & 4 & 5 & 7 & 35 & 42 & 35 & 32 & 0 \\
\hline $\mathrm{F}$ & 4 & 6 & 2 & 35 & 37 & 35 & 33 & 2 \\
\hline$G$ & 5 & 7 & 5 & 42 & 47 & 32 & 22 & 0 \\
\hline $\mathrm{H}$ & 5 & 8 & 2 & 42 & 44 & 22 & 17 & 2 \\
\hline I & 7 & 9 & 5 & 47 & 52 & 17 & 0 & 0 \\
\hline
\end{tabular}

Berdasarkan tabel 5 yang sudah diketahui TF untuk setiap pekerjaan, maka dapat disimpulkan bahwa pekerjaan A-B-C-D-E-G-I merupakan pekerjaan yang dilewati jalur kritis dan memiliki total durasi kritis yaitu 52 hari, artinya pekerjaan tersebut tidak dapat ditunda. Hal ini dapat membantu Project Manager untuk mengetahui apakah proyek dapat berjalan sesuai rencana atau tidak. Kemudian dari durasi kritis yang sudah diketahui, dapat digunakan untuk menghitung nilai probabilitas proyek apakah dapat selesai sesuai waktu yang direncanakan atau tidak. Gambar 3 berikut merupakan gambar network diagram dari proyek ini, dan jalur tanda panah berwarna merah merupakan jalur kritisnya. 


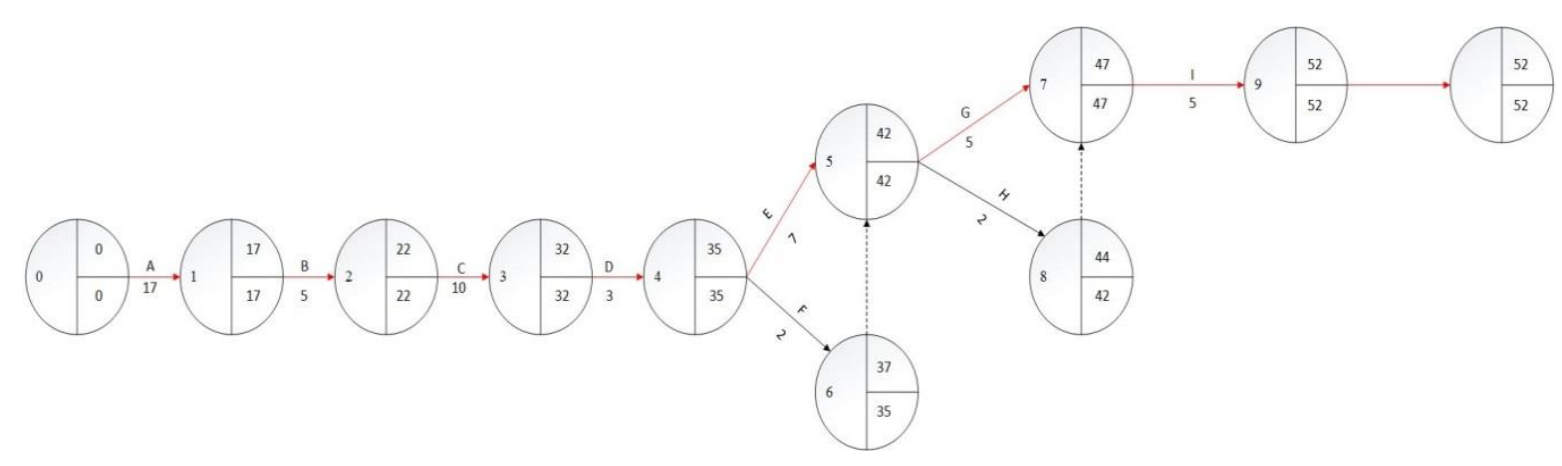

Gambar 3 Network Diagram

Langkah selanjutnya setelah diketahui jalur kritis dan durasi kritisnya, maka dilakukan perhitungan probabilitas proyek. Dalam menggunakan probabilistik PERT menggunakan asumsi bahwa suatu kegiatan secara statistik bersifat independen dan waktu selesainya proyek terdistribusi secara normal.Rata-rata selesainya proyek merupakan jumlah waku dari kegiatan kritis, sedangkan varian lintasan kritis proyek merupakan jumlah varian kegiatan kritis [2].

Berdasarkan hasil perhitungan diagram jaringan dan jalur kritis di hasilkan bahwa jalur A, B, C, D, E, G, I merupakan jalur kritis.

$$
\begin{aligned}
\text { Jalur Kritis } & =\text { A, B, C, D, E, G, I } \\
& =17+5+10+3+7+5+5 \\
\text { Durasi Kritis } & =52 \\
\text { Standard Deviasi } & =\text { A, B, C, D, E, G, I } \\
& =1+0,5+0,84+0,67+1+0,34+0,34 \\
& =4,69
\end{aligned}
$$

Setelah mendapatkan nilai dari jalur kritis dapat di hitung nilai probabilitas bahwa waktu penyelesaian proyek adalah kurang dari 66 hari, maka:

$$
\begin{aligned}
\mathrm{Z}= & \frac{\mathrm{Ts}-\mathrm{Te}}{\sqrt{\sum\left(S^{2}\right)}} \\
& =\underline{66-52} \\
& \sqrt{\sum\left(4,69^{2}\right)} \\
& =\frac{14}{21,9} \\
& =0,639 \sim 0,6
\end{aligned}
$$

Berdasarkan tabel Z Value \& Probability, probability untuk Z sebesar 0,6 adalah 0,7257. Dengan demikian, diperkirakan bahwa probabilitas proyek ini selesai dalam waktu kurang dari 66 hari adalah $72 \%$.

Berdasarkan penelitian (Arianie dan Puspitasari, 2017) menjelaskan bahwa penjadwalan proyek mengggunakan metode PERT dapat diketahui probabilitas keberhasilan suatu proyek, sehingga dapat meminimalisasi lebih awal terjadinya kerugian biaya akibat kemungkinan keterlambatan proyek [1].

\section{PENUTUP}

\section{Kesimpulan}


Berdasarkan penelitian yang telah dilakukan mengenai analisis estimasi waktu penyelesaian proyek perangkat lunak menggunakan metode PERT, maka dapat diambil kesimpulan bahwa Project Manager perlu membuat uraian struktur pekerjaan, kemudian menentukan tiga nilai estimasi durasi untuk setiap pekerjaan, setelah diketahui estimasi durasinya maka perlu digambarkan network diagram untuk mengetahui pekerjaan mana yang tidak memiliki Total Float yang artinya pekerjaan yang melewati jalur kritis dan dapat diketahui total durasi kritisnya, sehingga hasil dari durasi kritis dapat digunakan untuk mengetahui probabilitas keberhasilan suatu proyek, dan hal ini dapat digunakan sebagai acuan bagi Project Manager untuk melakukan perencanaan jadwal proyek selanjutnya.

\section{Saran}

Berdasarkan penelitian yang sudah dilakukan, maka saran untuk penelitian selanjutnya adalah perlu dilakukan analisis lebih lanjut mengenai hubungan presentasi probabilitas keberhasilan suatu proyek dengan anggaran biaya yang harus dikeluarkan untuk penyelesaian proyek.

\section{DAFTAR PUSTAKA}

[1] Arianie, G.P, dan Puspitasari N.B, Perencanaan Manajemen Proyek dalam meningkatkan Efisiensi dan Efektifitas Sumber Daya Perusahaan (Studi Kasus: Qiscus Pte Itd). JATI Undip: Jurnal Teknik Industri, Vol. 12, No. 3, September 2017.

[2] Aris Munandar, M, Sistem Informasi Manajemen proyek pada PT. Excellent Infotama Kreasindo, 2017.

[3] Mas'ud M.I, dan Wijayanti E. Analisis Evaluasi Biaya dan Penjadwalan Waktu Proyek Pengolahan Limbah PT. KI dengan pendekatan PERT. Jurnal J-Ensitec: Vol 03 No.02, Mei 2017

[4] Sharma, S.C, Operation Research PERT, CPM, and Cost Analysis. New Delhi, India: Discovery Publishing House. 2006. 